\title{
A DIRECTOR'S DUTY TO CONFESS: A MATTER OF GOOD FAITH?
}

\author{
Lusina Ho* AND Pey-WoAn LeE**
}

\section{INTRODUCTION}

IN common law jurisdictions, there has been considerable academic and judicial discussion of the duties of company directors generally. In contrast, relatively little ink has been spent on the specific duty, if any, of a company director to disclose his own misconduct (in the civil realm) to the company, even less so on the nature and basis of such a duty. This is unsurprising given the very restrictive approach to disclosure obligations in English law. Thus, while a director may in loose terms be said to be under a "duty" to disclose interests that conflict with the company's, such disclosure only serves the purpose of relieving him from liability, and failure to do so per se has not been regarded as an independent source of liability. ${ }^{1}$

A spate of recent decisions relating to the subject may, however, prove to be straws in the wind. Chief amongst them is Item Software (UK) Ltd. v. Fassihi, ${ }^{2}$ in which the English Court of Appeal held that a director owes a positive duty to disclose his own misconduct to the company, the breach of which would give rise to a claim for remedies. Arden L.J., who delivered the judgment of the court, held that such a requirement stems from a director's fundamental duty to act in good faith in the best interests of the company, and that this duty is fiduciary in nature. In adopting this broad formulation of the fiduciary duty, her Ladyship relied on judicial statements in several first instance decisions, such as Tesco Stores Ltd. v. Pook ${ }^{3}$ and Crown

* Professor, Faculty of Law, The University of Hong Kong. Our thanks to Peter Chau, Joe Lau, Rebecca Lee, Cliff Lui, Anselmo Reyes, and Peter Watts for their valuable comments on earlier drafts of the article.

** Assistant Professor, School of Law, Singapore Management University.

${ }^{1}$ See National Mutual Property Services (Australia) Pty. Ltd. \& Ors. v. Citibank Savings Ltd. [1998] F.C.A. 564; Breen v. Williams (1996) 138 A.L.R. 259 esp. at p. 289; R. Nolan, "A Fiduciary Duty to Disclose?" (1997) 113 L.Q.R. 220; P. Parkinson, "Fiduciary Law and Access to Medical Records: Breen v Williams" (1995) 17 Sydney L. Rev. 433. See text to nn. $22-27$. This does not, of course, affect directors' statutory obligations of disclosure, see text to n. 68 et. seq.

2 [2004] EWCA (Civ) 1244; [2005] 2 B.C.L.C. 91. Noted, J. Armour \& M. Conaglen, "Directorial Disclosure" [2005] C.L.J. 48; A. Berg, "Fiduciary Duties: A Director's Duty to Disclose His Own Misconduct" (2005) 121 L.Q.R. 213.

3 [2003] EWHC 823; [2004] I.R.L.R. 618. 
Dilmun v. Sutton, ${ }^{4}$ as well as academic commentary in the United States about the meaning of fiduciary loyalty. ${ }^{5}$ Her Ladyship's formulation also echoes that of Hart J. in British Midland Tool Ltd. v. Midland International Tooling Ltd., ${ }^{6}$ which was decided shortly before Fassihi.

The Fassihi decision has quickly proven to be controversial, having already generated two starkly opposite responses in judicial decisions in England and Australia. In $P \& V$. Industries Pty. Ltd. v. Anthony Porto ${ }^{7}$ Hollingworth J. of the Supreme Court of Victoria, Australia, severely criticised Fassihi for its unsatisfactory reasoning and failure to consider contrary Commonwealth decisions. ${ }^{8}$ In Porto, a claim against a fiduciary for breach of the fiduciary duty to disclose his past (fiduciary) wrongdoing was rejected on the ground that "the no conflict and no profit rules encompass the whole content of fiduciary obligations", which are proscriptive and do not prescribe any positive duties. ${ }^{9}$ The Australian conception of the fiduciary duty was said to be different from England and North America. ${ }^{10}$

In contrast, in Shepherds Investments Ltd. \& Anor. v. Andrew Walters \& Ors. ${ }^{11}$ Etherton J. of the English Divisional Court warmly adopted the broad formulation of fiduciary duty in Fassihi. In deciding which preparatory step(s) taken by a director to set up a rival company amounted to a breach of fiduciary duty, Etherton J. need not have applied the broad formulation of fiduciary duty in Fassihi, but chose to do so. ${ }^{12}$ Significantly, his Lordship rejected counsel's suggestion to treat (a) the taking of impermissible preparatory steps in breach of the director's obligations, and (b) the duty to disclose such a breach, as involving two distinct fiduciary duties. ${ }^{13}$ Instead, it was emphasised that following Fassihi, the "single and overriding touchstone is the fundamental duty of a director to act in what he considers in good faith to be in the best interests of the company"; 14 particular facts about non-disclosure or taking impermissible steps only provide the context in which this broad duty applies.

${ }^{4}$ [2004] EWHC 821; [2004] 1 B.C.L.C. 468.

5 See [2005] 2 B.C.L.C. 91 at [42] and [43], Arden L.J. cited as applicable to English law the American work of R. C. Clark, Corporate Law (Boston 1986) at pp. 34 and 141, in which the author used the expression, "the fiduciary duty of loyalty". At para. [44], her Ladyship described the duty of loyalty as a "fiduciary principle".

6 [2003] EWHC 466; [2003] 2 B.C.L.C. 523 at para. [89].

[2006] V.S.C. 131

See P. Watts, "The Transition from Directors to Competitors" (2007) 123 L.Q.R. 21, at p. 24 for the view that Porto was mistaken.

9 [2006] V.S.C. 131 at [23].

${ }_{10}$ Ibid., at para. [42].

11 [2006] EWHC 836. Noted, P.W. Lee \& L. Ho, "A Director's Liberty to Compete" [2007] J.B.L. 98; and P. Watts, note 8 above.

12 [2006] EWHC 836 at para. [106].

13 Ibid., at para. [132].

14 Ibid. 
Fassihi and the conflicting judicial responses that ensued bring into sharp focus difficult issues as to the orthodoxy of a positive fiduciary duty of disclosure, the legal basis of this duty, and the nature of fiduciary duties. The present article seeks to examine these issues. Part One will take stock of the new developments through closely comparing them with existing principles. Part Two will consider the possible bases on which a fiduciary duty of disclosure may be justified. In this part, the authors argue that given the existing stage of legal developments, this specific duty can be justified as an application of a director's duty to refrain from acting with the intention to prejudice the company's interests, and that this duty is fiduciary in nature. It is submitted that such a justification is in line with the parameters of fiduciary principles, in particular those set forth in Bristol \& West Building Society v. Mothew ${ }^{15}$ as well as recent legislative developments in the UK corporate context, which will be discussed in Part Three.

\section{A New Frontier of Liability}

In Fassihi, the English Court of Appeal held that a director (Mr. Fassihi) who encouraged his managing director to take a hard line in negotiations with a third party, but who surreptitiously attempted (but failed) to usurp the relevant business opportunity, owed and breached a positive duty to disclose his own misconduct to the company. On the rather unique facts found by the trial judge, the managing director's uncompromising negotiating stance was not caused by Mr. Fassihi's encouragement; however, knowledge of the latter's misconduct would have so shocked the managing director as to cause him to relent and accept the third party's proposal. Accordingly, even though Mr. Fassihi escaped liability for diverting and sabotaging the business opportunity, he was held liable for failing to disclose his intention and attempt to compete with the company. ${ }^{16}$

Arden L.J. reached this conclusion despite the long-standing principle laid down by the House of Lords in Bell v. Lever Brothers, ${ }^{17}$ viz. an employee owes no duty to disclose his own breach of duty to the employer, not even before he signed a termination agreement with the latter. Her Ladyship claimed to have found support ${ }^{18}$ from recent decisions in Tesco Stores Ltd. v. Pook, ${ }^{19}$ Crown Dilmun v. Sutton, ${ }^{20}$ and Bhullar v. Bhullar. ${ }^{21}$ A closer look at these authorities is now in order.

15 [1998] Ch. 1.

16 There was no appeal against the finding of facts by the trial judge.

17 [1932] A.C. 161.

Fassihi, note 2 above, at paras. [39] and [40].

19 Note 3 above.

20 Note 4 above.

21 [2003] EWCA Civ 424; [2003] 2 B.C.L.C. 241. 


\section{A. Disclosure under the Fiduciary Rules}

The basic propositions of the no-conflicts and no-profit rules are well established. A fiduciary should not take any opportunity which might put him in a (real sensible) possibility of conflict with his beneficiaries. ${ }^{22} \mathrm{He}$ must account for any profits obtained as a result of breaching these rules, unless he has made full and frank disclosure of his conduct to the beneficiary, and the latter has consented to his actions. In this context, despite use of the language of a "duty" to disclose conflicting interests, non-disclosure per se is not actionable; it only deprives the fiduciary of the defence of consent. ${ }^{23}$

It is true that some recent decisions in this area appear to impose liability on a broader basis involving non-disclosure, by holding that a director who comes across information that is of commercial interest to his company should report it to the latter, and must account for profits obtained as a result of exploiting the information himself. Thus, in Bhullar v. Bhullar, two company directors who purchased neighbouring property they came across as passers-by, without informing the company of the opportunity or the subsequent purchase, were held liable for breaching the conflict rules. Liability was imposed even though the company had resolved to suspend its usual business of property investment during that period. In a similar vein, in Crown Dilmun v. Sutton, ${ }^{24}$ Peter Smith J. held that under the conflict rules, a director owed a duty to exploit every relevant opportunity that came his way (whether personally or not) for the benefit of the company, the only exception being when he has obtained the company's consent after making full and frank disclosure. ${ }^{25}$ Both decisions applied I.D.C. v. Cooley, ${ }^{26}$ where a director was held liable for exploiting an opportunity offered to him personally without passing it on to the company. ${ }^{27}$

Significantly, in these cases, it is the director's failure to inform the company of the opportunity, combined with his subsequent exploitation of it in conflict with the company's interests, that render him liable. Accordingly, they do not support the suggestion that nondisclosure of the opportunity to the company is per se sufficient to

22 Per Lord Upjohn in Boardman v. Phipps [1967] 2 A.C. 46. Lord Upjohn's dissenting judgment was repeatedly endorsed in subsequent cases such as Industrial Development Consultants Ltd. v. Cooley [1972] 1 W.L.R. 443; Queensland Mines Ltd. v. Hudson (1978) 52 A.L.J.R. 399.

23 See Fassihi [2005] 2 B.C.L.C. 91 at para. [40]; cf. Horcal Ltd. v. Gatland [1983] B.C.L.C. 60, pp. 66 -68 and Item Software (UK) Ltd. v. Fassihi [2003] 2 B.C.L.C. 1 (Ch. D) at para. [54(c)].

24 Note 4 above.

25 Ibid., at para. [179].

26 Note 22 above.

27 The reference in Cooley to the so-called duty to pass the information on to the company was explained in Nottingham University v. Fishel [2000] I.R.L.R. 471 at [103] on a narrower basis, viz. the director was under a specific duty to obtain a certain type of contract for a company, and the opportunity that came to him fell within such types of contracts. 
found liability. It follows that Fassihi appears to have extended the principles affirmed in these decisions in at least three aspects: first, from specific reference to disclosure of a business opportunity that is likely to be of interest to the company, Fassihi derives a general duty on the part of the director to disclose his own misconduct; secondly, such a duty is fiduciary in nature, with possible implications for other non-director fiduciaries such as agents, solicitors, and partners; thirdly, and most significantly, Fassihi appears to have made nondisclosure an independent cause of action.

\section{B. Disclosure in Employment Law}

Bell v. Lever Brothers has laid down the general principle governing disclosure in the employment context, namely that an employee owes no general duty to disclose his own misconduct to the employer, and that is so even before signing a termination agreement with the latter. In a similar vein, he does not owe a general duty to disclose the misconduct of his fellow employees, save when the terms and circumstances of employment are such that an employee is placed in a position of hierarchy to report the conduct of his superiors or subordinates to the employer; in such circumstances, he must disclose the misconduct of his fellow employees, even though this will reveal his own misconduct and entitle the employer to dismiss him. ${ }^{28}$ Accordingly, in Sybron Corporation v. Rochem Ltd, a senior executive who had responsibility to make monthly reports about a geographical sector placed under his supervision was held liable for failing to disclose the breaches of his subordinates; it was irrelevant that disclosure would also reveal his own breach as their conspirator. ${ }^{29}$ Most recently, in British Midland Tool Ltd. v. Midland International Tooling Ltd., Hart J. applied Sybron Corporation to hold that three of six directors who continued in office owed and breached the duty to report a serious attempt by a competitor (who was a former director) to poach staff of the principal company. ${ }^{30}$

However, none of this long line of cases held that, independent of any duty to disclose his fellow employee's misconduct, a director has a duty to disclose his own misconduct; it is likewise undecided whether any such duty is fiduciary in nature or not. The issue has only been considered in judicial dicta, with conflicting views. ${ }^{31}$ In the run up to

28 Swain v. West (Butchers) Ltd. [1936] 1 All E.R. 224; [1936] 3 All E.R. 261, CA.

29 [1984] Ch. 112.

30 Note 6 above.

31 See the different views of Lord Atkin (obiter, apparently in support of the duty) and Lord Thankerton (who seemed to take the contrary view, save in cases of fraudulent concealment) in Bell v. Lever Brothers, note 17 above (at pp. 227-8 and 231 respectively); of Glidewell J., at first instance (in support of the duty), and Goff L.J., on appeal, in Horcal Ltd. v. Gatland, note 23 above; and obiter support of the duty by May L.J. in Van Gestel v. Cann [1987] C.L. 454, C.A., and Peter Smith J. in Crown Dilmun v. Sutton, note 4 above. 
Fassihi, Peter Smith J. observed (also obiter) in Tesco Stores Ltd. v. Pook that directors - as opposed to employees - owe a duty to disclose breaches of their fiduciary duty. ${ }^{32}$ In his Lordship's view, such a principle can avoid the oddity arising from the Sybron line of cases, that while a director owes no duty to confess, he can be compelled to do so in the course of complying with his duty to disclose the misconduct of his fellow employees. ${ }^{33}$ In a dictum in Crown Dilmun v. Sutton, Peter Smith J. reiterated his view that a director (as a fiduciary) had a duty to disclose his own misconduct. His Lordship cited only his own judgment in Tesco Stores Ltd. v. Pook in support and provided no explanation.

In Fassihi, Arden L.J. cited Crown Dilmun v. Sutton and Tesco Stores Ltd. v. Pook in support, but did not note that the observations in these cases are only dicta. Moreover, her Ladyship interpreted Bell v. Lever Brothers narrowly as holding that, in the circumstances of that case, the employees owe no duty to confess before the signing of the termination agreements, but not that there was no general duty to confess.

Given Arden L.J.'s observations, it is submitted that Fassihi has significantly extended the scope of the duty of disclosure in the following ways: first, before Fassihi, there was no binding authority requiring directors to confess except as an incidental consequence of his duty to disclose the misconduct of fellow employees; after the decision, directors owe a duty to confess even in the absence of disclosure of others' misconduct. Secondly, if the obiter observations of Arden L.J. about Bell v. Lever Brothers were followed, employees may, in appropriate circumstances, owe a duty to confess, although her Ladyship did not indicate what these circumstances might be.

This brief survey has sought to show that the duty imposed in Fassihi appears to be an extension of existing legal principles. The question that ensues is whether such a development is defensible, and if so, on what grounds. ${ }^{34}$

\section{The Requirement to Confess as a Fiduciary Duty?}

In Fassihi, Arden L.J. did not justify this apparently novel duty of disclosure as belonging to the director's duty of care or the fiduciary rules on secret profits and conflict of interest. Nor did her Ladyship consider it to be a director's "separate and independent duty to disclose his own misconduct to his principal or more generally

32 Note 3 above.

33 Ibid., at para. [66]

34 See also Helmut Integrated Systems Ltd. v. Tunnard [2006] EWCA Civ 1735 at para. [41]. 
information of relevance and concern to it". ${ }^{35}$ Arden L.J. stressed that the Court's conclusion on liability was based on the "fundamental duty to which a director is subject, that is the duty to act in what he in good faith considers to be the best interests of the company". ${ }^{36}$ Without elaboration, her Ladyship called this a duty of loyalty, and assumed that it was fiduciary in nature. ${ }^{37}$

Such an analysis presents numerous difficulties, not least the uncertainties regarding the scope and content of the duty to act in good faith in the best interests of the company, and in turn whether it is a duty of loyalty and is fiduciary in nature. To answer these questions, it is necessary to start by examining how Arden L.J. derived the conclusion of liability from the director's duty to act in what he in good faith considers to be the best interests of the company.

\section{A. The Requirement to Confess as an Application of a Director's Fundamental Duty}

In saying that Mr. Fassihi's liability was based on a director's "fundamental" duty to act in what he in good faith considers to be in the best interests of the company, Arden L.J. had not explained how exactly the disclosure requirement was derived from the fundamental duty. Her Ladyship merely remarked that this duty was expressed "in very general terms" and was "capable of application in cases where it [had] not previously been applied". ${ }^{38}$ It was nonetheless emphasized that on the facts, Mr. Fassihi could not reasonably have believed that it was not in the company's best interests to know about his breach. ${ }^{39}$

In light of these disparate observations, Arden L.J. might mean to say that the requirement on the director to disclose his misconduct is but an instance of the application of the fundamental duty, for the following reason. A director has the duty to act in what he in good faith considers to be in the best interests of the company. Acting in the best interests of the company includes informing it of matters that would be in its best interests to know about. Thus, if a director in good faith considers it to be in the company's best interests to know about his misconduct, then the fundamental duty entails - on such facts that he should disclose his misconduct to the company.

Explained this way, Mr. Fassihi was held liable not because of the imposition of a novel or independent duty of disclosure on directors, but rather as the result of the application of the director's fundamental

35 Fassihi, note 2 above, at para. [41]. The latter broad view was similarly rejected by Elias J. in Fulham Football Club (1987) Ltd. v. Tigana [2005] I.S.L.R. 32.

${ }^{36}$ Fassihi, note 2 above, at para. [41].

37 Fassihi, note 2 above, at paras. [41] to [44].

38 Note 2 above, para. [41].

39 Note 2 above, para. [44]. 
duty to the facts of that case. It also follows that the director is required to disclose his own misconduct when, but only when, he has formed the belief (that is when he considers in good faith) that it is in the company's best interests to know about his misconduct. However, this does not mean that a director could avoid liability by simply asserting that he did not have the requisite belief, for the Court of Appeal in Fassihi assessed the facts objectively in deciding that Mr. Fassihi had the belief. As the company was actively seeking to renew the contract with the third party, it was reasonable to infer, as Arden L.J. did, that Mr. Fassihi could not have believed that it was not in the company's best interests to know about his simultaneous and ongoing attempt to divert the business opportunities; his omission to disclose was due to the presence of male fides. If it was merely an unconscious omission to disclose, ${ }^{40}$ there would not be any breach of the duty intentionally to promote the company's best interests. This understanding of Arden L.J.'s reasoning finds support in the subsequent decision of Shepherds Investments Ltd. v. Andrew Walters \& Ors. ${ }^{41}$ In that case, the court had to consider, inter alia, whether the defendant directors were in breach of their fiduciary duties to the company in taking preparatory steps to set up competing businesses prior to their resignation. Following Arden L.J.'s reasoning in Fassihi, Etherton J. regarded the director's fundamental duty of good faith as the "single and overriding touchstone" 42 of liability. On the facts, the defendants breached this duty when they formed the irrevocable intention to set up a rival business without disclosing the same to the company. ${ }^{43}$ Like Mr. Fassihi, the defendants in Shepherds Investments knew, or must reasonably have believed, that the failure to disclose their competing activities would prejudice the claimant company.

Such an application of a director's duty intentionally to promote the best interests of the company gives rise to at least two difficulties for future courts. First, Arden L.J. did not clarify whether the presence of the belief that certain acts are in the best interests of the company is per se sufficient to give rise to a duty to do those acts. More specifically, her Ladyship had not required that the omission itself involved a breach of duty independently of the duty intentionally to promote the best interests of the company. ${ }^{44} \mathrm{Without}$ this requirement,

40 For example, on the facts of Regal (Hastings) Ltd. v. Gulliver [1967] 2 A.C. 134 or Boardman v. Phipps [1967] 2 A.C. 46, where the principal had rejected the business opportunity with full knowledge, it is plausible that a fiduciary who subsequently pursues it himself holds a bona fide belief that the principal would not be interested in knowing about his pursuit.

41 Note 11 above.

42 Note 11 above, at para. [132].

${ }^{43}$ Note 11 above, at para. [127].

${ }^{44}$ For example, on the facts of Fassihi, the failure to disclose did not by itself involve a breach of the director's duties under the employment contract, statute, or the fiduciary conflict and profit rules. His attempt to divert and to sabotage the company's maturing business opportunity did involve a 
the presence of the requisite belief can render as a breach an act or omission that would otherwise be innocuous. Bearing in mind that the courts can infer the belief from the facts objectively, Arden L.J.'s analysis opens up a broad avenue for imposing liability on a wide variety of acts and omissions upon the finding of the requisite belief by the court.

Secondly, Arden L.J. assumes that the duty to intentionally promote the best interests of the company is part of the director's duty of loyalty, and is therefore also a fiduciary duty. This raises the difficult question as to whether such a duty, albeit being a "fundamental duty" of a director, is indeed fiduciary in nature, bearing in mind that not every duty owed by a fiduciary is a fiduciary duty. ${ }^{45}$ If it is indeed a fiduciary duty, the remedies will be more extensive. Any characterisation of this fundamental duty as fiduciary in nature will need to overcome the increasingly popular view that: (a) fiduciary duties are negative or proscriptive in nature, leaving no room for any positive fiduciary duty; and (b) a fiduciary's duty to act in the best interests of the beneficiary or to provide "best advice" through disclosing information is of a quasi-tortious or contractual nature, and not a fiduciary duty. ${ }^{46}$ It is submitted that these are not insuperable hurdles; rather, the greatest difficulties in determining whether this fundamental duty is fiduciary in nature are the lack of a clear definition of fiduciary duty, and even lesser clarity in the content of this fundamental duty.

\section{Fiduciary Duties only Proscribe Conduct?}

The view that fiduciary duties are proscriptive has received support in judicial decisions ${ }^{47}$ and academic commentaries. ${ }^{48}$ The arguments that have been put forward may be summarised as follows. Where a person undertakes to act in the best interests of another, there is the risk given human weaknesses - that his performance is inhibited by selfinterests or conflicting duties. To ensure his single-minded loyalty in

breach of the conflict rule, though it had not resulted in any loss or gain. However, before the Fassihi decision, non-disclosure of such misconduct did not amount to a breach of duty.

45 Mothew, note 15 above, p. 16.

46 See Breen, note 1 above, p. 289, per Gummow J; Aequitas v. A.E.F.C. [2001] NSWSC 14, (2001) 19 A.C.L.C. 1006 at paras. [287] and [288].

47 See Breen, note 1 above; Citibank, note 1 above; Aequitas v. A.E.F.C., note 46 above; see more recently $P \& V$ Industries Pty. Ltd. v. Anthony Porto, note 7 above.

48 See P. D. Finn, Fiduciary Obligations (Sydney 1977), at para. [30]; and by the same author, "The Fiduciary Principle", Ch. 1 of T. G. Youdan (ed), Equity, Fiduciaries and Trusts (Toronto 1989), p. 26; Nolan, note 1 above; Parkinson, note 1 above; P. J. Millett, "Equity's Place in the Law of Commerce" (1998) 114 L.Q.R. 214, pp. 222-3; S. Worthington, "Fiduciaries: When is Self-Denial Obligatory?" (1999) 58 C.L.J. 500; R. Flannigan, "Fiduciary Duties of Shareholders and Directors" [2004] J.B.L. 277; J. Glover, Commercial Equity: Fiduciary Relationships (Sydney 1995) at para. [5.51] and p. 163 et seq.; J. A. McGhee et. al., Snell's Equity (31 ${ }^{\text {st }}$ edn) (London: 2005) at paras. [7]-[19]. 
order to facilitate the performance of the primary task, fiduciary duties are imposed..$^{49}$ They do so by freeing the fiduciary's judgement from the biases of conflicting personal (or third party) interests. ${ }^{50}$ In exacting loyalty, fiduciary duties must not unduly limit the manager's discretion. As the prescription of a positive standard of loyal behaviour (such as the duty to act in good faith to promote the beneficiary's best interests) is vague and uncertain in application, and thus will most likely have a chilling effect on managerial discretion, fiduciary law operates by excluding clearly-defined conducts involving conflicts of interests from the permissible realm. ${ }^{51}$

Though powerful, this is an argument based on practicality rather than the conceptual nature of the duty of loyalty; it does not claim that the concept of loyalty cannot canvass positive duties. In fact, in avoiding a conflict of interest (or duty), a fiduciary often needs to take positive actions. For example, it has been held, in the company context, that directors who are (exceptionally) found to have transacted with shareholders in a fiduciary capacity are obliged to make full disclosure of material facts relating to the transaction. ${ }^{52}$ In a similar vein, a solicitor who (with the relevant consent) acts for two principals with conflicting interests is obliged to fulfil his fiduciary obligation by disclosing material information to one principal even if that means breaching his duty to the other. ${ }^{53}$ It is true that in these instances, disclosure is required in the context of positive conducts such as entering into transactions or representing principals with conflicting interests. The point remains, though, that in appropriate circumstances, fiduciary duties can compel positive acts; the concept of loyalty is not repugnant to the imposition of positive duties.

Rather, it is submitted that the gist of the controversy is not so much how fiduciary duties operate, but the policy issue of how onerous such duties should be, bearing in mind the need to preserve managerial discretion. It is conceivable that an appropriately qualified duty of a positive nature can meet this practical concern. The facts and result of Fassihi, although perhaps not its reasoning, may provide a neat illustration. Mr. Fassihi was attempting a breach of fiduciary duty and deliberately concealing his attempt to sabotage negotiations

49 M. Conaglen, "The Nature and Function of Fiduciary Loyalty" (2005) 121 L.Q.R. 452.

50 Glover, note 48 above, at para. [5.51].

51 R. Nolan, "The Legal Control of Directors' Conflicts of Interest in the United Kingdom: NonExecutive Directors Following the Higgs Report" (2005) 6 Theoretical Inquiries in Law 413, pp. 422-423, where the author argues that fiduciary duty principally proscribes conduct.

52 Coleman v. Myers [1977] 2 N.Z.L.R. 225. This decision has been endorsed and applied in England (Platt v. Platt [1999] 2 B.C.L.C. 745) and Australia (Brunninghausen v. Glavanics (1999) 46 N.S.W.L.R. 538). Cf. Flannigan, note 48 above, pp. 295 - 299. For other instances of positive fiduciary obligations, see R. Pennington, Pennington's Company Law ( $8^{\text {th }}$ edn.) (London 2001), p. 720 .

53 Moody v. Cox \& Hatt [1917] 2 Ch. 71; Hilton v. Barker Booth \& Eastwood [2005] 1 W.L.R. 567. 
that the company was actively pursuing. Not only can it be said that he believed disclosure was in the best interests of the company, but also that non-disclosure was prejudicial to its interests. On these facts, it is submitted that the imposition of liability on Mr. Fassihi for nondisclosure did not violate his managerial discretion. After all, it was Mr. Fassihi's own judgment that disclosure was in the company's best interests, and arguably also that non-disclosure was prejudicial to its interests; until he had formed this belief, there was no liability. ${ }^{54}$

In addition, if one takes a more cautious formulation than that adopted in Fassihi, by qualifying the duty as one that requires the director to refrain from acts or omissions that he believes are prejudicial to the company's interests, such a duty is not too onerous. This duty is significantly narrower than the Fassihi duty because its focus rests on the director's own belief of the prejudice or harm (as opposed to merits) of his management decision. Under this approach, the risk of second-guessing management decisions is minimised because the propriety of a director's conduct is only called into question where the management decision is clearly perceived by him to be prejudicial to the company. Thus, such a duty will not hold liable a director who has not acted with the proactive intention of advancing the best interests of the company, but who also has not intentionally prejudiced the company's interests. Such a director may not be very loyal, but is arguably still not disloyal. It is different, of course, if he has acted (or omitted to act) as a result of a positive intention to prejudice the company's interests. Similar to the duty invoked by Arden L.J., namely to act in what the director believes to be in the company's best interests, the proposed duty can compel positive acts. It is submitted that if liability is imposed only upon finding such a disloyal intention, the duty is not too onerous, and the objections based on the allegedly proscriptive nature of fiduciary duties are met.

It is possible, of course, to take the duty one step further by asking: since the law is prepared to employ a prophylactic approach to all cases involving conflicts, should not like treatment be applied to the obligation to confess breaches of conflict rules, such that the obligation should arise in all cases whether or not intentional conduct could be inferred from the circumstances? In our view, having particular regard to the legislative development discussed below, ${ }^{55}$ such a development would not be wholly unmeritorious. ${ }^{56}$ Such an obligation would help

54 Admittedly, to the extent that the courts infer the existence of this belief objectively, the scope of managerial discretion might be compromised.

55 See text to note 70 below et seq.

56 Support may, for instance, be derived from an economic analysis of the benefit of mandatory disclosure: see the Law Commissions' consultation paper, Company Directors: Regulating Conflicts of Interests and Formulating a Statement of Duties, Consultation Paper No.153, at paras. $[3.58]-[3.62]$. 
bolster the conflict rules: once the director engages in a conflict of interest, he is required to disclose it; and once disclosure is made, he will not be able to proceed further without impunity. ${ }^{57}$ However, such a development will represent a significant extension of fiduciary law that is justifiable only on policy grounds, and is therefore best undertaken by the legislature.

\section{Duty of Care versus Fiduciary Duty}

Another objection to a positive fiduciary duty is that a duty to act positively in the best interests of the beneficiary through disclosing information is of a quasi-tortious or contractual nature, and not a fiduciary duty. ${ }^{58}$ Under such a view, "fiduciary obligations often arise in cases where one person is under an obligation to act in the interests of another, but that does not mean that the obligation to act in the interests of another is a fiduciary obligation". ${ }^{99}$ In this broad formulation, it is indeed plausible to see the duty as contractual (in guaranteeing that the result of the incumbent's acts is in another's interests) or tortious (as it is in another's interests that the incumbent acts, say, with care), and not necessarily fiduciary in nature. ${ }^{60}$

However, if, as in Fassihi, the positive duty of disclosure is qualified by requiring the incumbent to refrain from acting with the intention to prejudice another's interests, it is submitted that such a duty is fiduciary in nature. Given that the very essence of the fiduciary duty is to ensure single-minded loyalty on the part of the fiduciary, ${ }^{61}$ it is difficult to see how a fiduciary who intentionally harms the beneficiary's interests is not disloyal. Moreover, this duty is clearly distinguishable from the tortious duty of care, in that lack of care is neither necessary nor sufficient for the breach; only the presence of a

57 Of course, it can be said that any director who engages in a conflict is unlikely to disclose it, such that the duty will invariably be breached every time a director breaches the conflict rules. It is submitted that precisely for this reason, the conflict rules will be rendered more effective; for a director who escapes the conflict rules can still be liable for non-disclosure, as the Fassihi decision shows. The policy concern to bolster the remedies for breaches of the conflict rules clearly played a part in the Court of Appeal's decision in Fassihi, note 2 above, at para. [63]. Arden L.J.'s appeal to economic arguments (at paras. [65] and [66]) to justify disclosure in this context also echoes those of the English Law Commission: see note 56 above.

58 See note 46 above. A related argument in support of this view is that prescriptive duties are the domain of contract and tort, see Citibank, note 1 above. Insofar as this objection is premised upon the view that fiduciary duties are only proscriptive, and hence any prescriptive duty can only fall within the domain of contract or tort, the point has been dealt with in the text to notes 44 to 54 . It is further submitted that the distinction between fiduciary and non-fiduciary duties should not rest on the form which the duty takes (i.e. whether it is prescriptive or proscriptive), but rather the nature of the duty.

59 Aequitas v. A.E.F.C., note 46 above, at para. [284] (emphasis supplied), referring to Breen, note 1 above.

60 See L. Smith, "The Motive, Not the Deed", in J. Getzler (ed.), Rationalizing Property, Equity and Trusts: Essays in Honour of Edward Burn (London 2003), p. 73.

${ }^{61}$ See the observations of Millett L.J. in Mothew, note 15 above, p. 18. 
disloyal intention will trigger liability. ${ }^{62}$ As observed by Millett L.J. in Bristol \& West Building Society v. Mothew, a loyal servant who does his incompetent best is not guilty of a breach of fiduciary duty. ${ }^{63}$

\section{B. Duty to Refrain from Intentionally Prejudicing the Company's Interests - a Fiduciary Duty}

Even if objections based on the proscriptive nature of fiduciary duties and confusion with the duty of care have been met, it can still be asked whether the duty to refrain from intentionally prejudicing the company's interests is a fiduciary duty. There is, admittedly, no existing authority directly affirming this proposition. Nor is there any clear judicial definition of fiduciary duty. The closest equivalent are recent observations in Bristol \& West Building Society v. Mothew, where Millett L.J. explained fiduciary duties as those duties of a fiduciary that are special to fiduciaries and attract remedies peculiar to the equitable jurisdiction. ${ }^{64}$ His Lordship did add that the essence of fiduciary duties is the single-minded loyalty of the fiduciary in the performance of his obligations; he did not define loyalty, but illustrated it by reference to a non-exhaustive list of the conflicts and profit rules. ${ }^{65}$

Notwithstanding so, it is submitted that based on the rules laid down by Millett L.J. pertaining to conflicts of duties, it would be reasonable to accept that a duty to refrain from intentionally prejudicing the principal's interests is fiduciary in nature. ${ }^{66}$ Millett L.J. held that under the fiduciary duty of loyalty, a fiduciary who acts on behalf of two principals with their consent must not intentionally further the interests of one to the prejudice of the other. ${ }^{67}$ While this duty to refrain from prejudicing the principal's interests is announced in relation to situations involving conflicts with the interests of another principal, it is submitted that it should still apply, and it is still fiduciary in nature, in the absence of such conflicts. This is because the presence of self-interests or the conflicting interests of a third party is just the most common reason why a fiduciary would intentionally prejudice the principal's interests and therefore breach his duty of loyalty. The underlying reasons for his breach of duty, however, should not be a necessary component of the duty. Accordingly, it is

62 Needless to say, the existence of a disloyal intention is necessary for a director's omission to confess to be a breach of fiduciary duty; for breaches of the conflicts- or profit-rules, it is wellestablished that such an intention is not necessary to establish liability.

63 Note 15 above, p. 18.

64 Ibid.

65 Ibid.

66 Note 15 above, pp. 18 and 21.

67 Millett L.J. held that the fiduciary must not intentionally further the interest of a principal to the prejudice of the other, and must not intentionally allow the performance of his obligation to one to be influenced by his relationship with the other: [1998] Ch. 1, pp. 18 and 19. 
submitted that a fiduciary who intentionally prejudices his principal's interests should still be in breach of his fiduciary duty, even though his breach may not be due to the presence of self-interests or the conflicting interests of a third party.

In a similar vein, despite their prominence, the conflicts or profit rules should not be treated as exhausting the fiduciary concept, and denying any room for an appropriately qualified fiduciary duty of a positive nature. ${ }^{68}$ Otherwise, a director who, say, acts (or fails to act) with the intention to prejudice his company's interests, but whose actions are not due to conflicting personal or third party interests, will still be treated as having acted loyally. ${ }^{69}$ In light of these observations, it is submitted that under existing equitable principles, a director's failure to disclose his continuing breach of fiduciary duty to his company while knowing that his failure is prejudicial to the company's interests is per se a breach of fiduciary duty. As the following Part will seek to show, the recent legislative developments in England appear to have the effect of recasting the director's obligation to disclose his interests in transactions with the company as a duty that is actionable per se.

\section{Disclosure And Corporate Regulation}

Where the misconduct in question is one that relates to a director's conflicting interests, regard should be had, in considering whether there is an actionable obligation to disclose the same, to the director's parallel disclosure obligations under the companies legislation. Thus, Arden L.J. did observe in Fassihi that "[the] fact that Mr. Fassihi stood to benefit if the contract was not approved would be such a benefit" 70 which he ought to have disclosed under section 317 of the Companies Act 1985, ${ }^{71}$ had a board meeting been convened for

68 P. Birks, "The Content of Fiduciary Obligation" (2000) 34 Is. L.R. 3, pp. 28-29 (republished at (2002) 16 T.L.I. 34, p. 47). Professor Birks observed that: "The obligation of disinterestedness cannot be severed from the obligation to promote and preserve. It does not make sense without that principal obligation. An independent obligation to abstain from pursuing interests of one's own is unintelligible, certainly unworkable." See also Tito v. Waddell (No. 2) [1977] Ch. 106 at 230, where Megarry V.C. pointedly observed: "If there is a fiduciary duty, the equitable rules about self-dealing apply, but self-dealing does not impose the duty. Equity bases its rules about self-dealing upon some pre-existing fiduciary duty: it is a disregard of this pre-existing duty that subjects the self-dealer to the consequences of the self-dealing rules. I do not think that one can take a person who is subject to no pre-existing fiduciary duty and then say that because he selfdeals he is thereupon subjected to a fiduciary duty."

69 See the discussion in the American decision of In re Walt Disney Co Derivative Litig. Civ., A. 15452 (Del. Ch. Aug. 9, 2005) (Chandler, V.C.), noted (2006) 119 Harv. L. Rev. 923, where the court accepts that it is a breach of fiduciary duty if a fiduciary intentionally disregards the beneficiary's interests in the absence of conflicting interests.

70 Fassihi, note 2 above, at para. [36].

${ }^{71}$ Companies Act 1985, s. 317(1) states that:"It is the duty of a director of a company who is in any way, whether directly or indirectly, interested in a contract or proposed contract with the company to declare the nature of his interests at a meeting of the directors of the company." This section has since been repealed and replaced by the Companies Act 2006, s. 182. 
purposes of approving the contract in question. This observation is significant because it serves to reinforce the fact that the disclosure obligation is not in and of itself a novel obligation. ${ }^{72}$ If not for the fortuitous fact that no board meeting was in fact conducted, $\mathrm{Mr}$. Fassihi would in any event have been obliged to disclose the nature and extent of his interest in the proposed transaction. While it is true, as Arden L.J. has observed, ${ }^{73}$ that section 317 did not of itself give rise to a civil remedy, the existence of a similar obligation in the legislative context does provide some measure of support for a similar development in the common law realm. First, such a disclosure obligation is not objectionable because it does not add to the practical burden of the director. Second and more significantly, any fear that the adjudication of such an obligation would involve the court in assessing the merits of the directors' commercial judgment - a principal objection to positive fiduciary obligations in general - may be allayed because to the extent that such risks exist, they are risks which judges are already legislatively mandated to undertake. Importantly, the recent legislative reform of directors' duties at general law in England may furnish further support for the conclusion in Fassihi.

The codification of directors' common law duties is a prominent feature of the UK government's ongoing effort to modernise the country's company law regulations. In general, the codified statement $^{74}$ seeks only to restate the principles as they exist at common law and in equity at the time of codification. ${ }^{75}$ By way of exception, however, the restatement departs from existing equitable principles in one material aspect. This involves the abolition of the requirement for seeking members' consent when directors are interested in proposed transactions ${ }^{76}$ with the company, and introduces in its place the "duty" to declare such interests, ${ }^{77}$ with a view to reflect widespread commercial practice of policing this

72 Indeed, the legislative disclosure obligations as regards conflicting interests were historically conceived for the purposes of bolstering the inadequate protection against agency and promoter problems at common law. For an account of this historical development, see P. Mahoney, "Mandatory Disclosure as a Solution to Agency Problems" (1995) 62 U. Chi. L. Rev. 1047, pp. $1055-1068$.

73 Fassihi, note 2 above, at para. [37]. On the uncertainty that still surrounds this issue, see P. W. Lee, "Reassessing the Crime of Non-Disclosure Under Section 317 of the Companies Act 1985" (2005) 5 J.C.L.S. 139, n. 20.

74 Companies Act 2006, ss. $170-181$.

75 Explanatory Notes to the Company Law Reform Bill 2005 (“Explanatory Notes”), at para. 301. See also Companies Act 2006, s. 170(4).

76 The Companies Act 2006 makes a distinction between interests in proposed transactions (s. 177) and existing transactions (s. 182) of the company. The former obligation falls under one of the directors' general duties, the breach of which is not underpinned by a criminal penalty (s. 183). In contrast, a failure to disclose interests in existing company transactions attracts criminal penalties. This dichotomy lends support to the view the failure to disclose interests in proposed transactions would in future give rise to civil remedies.

77 Companies Act 2006, s. 177. 
aspect of self-dealing through disclosure. ${ }^{78}$ This development has the effect of introducing into the corpus of directors' general duties at law a specific "duty" to disclose his or her interests in proposed company transactions. One of the present authors has also observed elsewhere that this development may in effect render disclosure the touchstone of liability when directors are interested in proposed company transactions. ${ }^{79}$ If this be correct, a director such as $\mathrm{Mr}$. Fassihi would be liable for any loss which the company may incur in connection with his breach. But the legislative development goes further than the Court of Appeal's decision in Fassihi, by imposing liability on every occasion of breach without regard to his subjective belief as to whether such disclosure would be in the company interests.

In the light of the legislative developments governing directors' interests in proposed transactions, the decision as regards the issue of disclosure in Fassihi does appear less remarkable. That is not, however, to deny the difficulties surrounding the delineation of the scope of positive fiduciary obligations. However, the proposition put forward in this Part is that where the obligation relates to the disclosure of conflicting interests, the recognition of such an obligation is or will in some measure be supported by the legislative framework.

\section{CONCLUSION}

The proposition that a director has the obligation to confess his own breach of fiduciary duty is undoubtedly, at first sight, a disconcerting one. The difficulties are compounded by the long-standing uncertainty over the meaning and scope of the "fiduciary" label, as well as the practical and policy concerns behind the primarily proscriptive rules governing a fiduciary's conflict of interest and secret profits. In this article, the authors have sought to make a very modest claim, that if a positive obligation to confess is founded on the basis of a director's duty to refrain from acting with the intention to prejudice the company's interests, it may be justified. This would primarily occur in circumstances where the omission is indicative of the director's disloyal intention. Such a duty to refrain from intentionally prejudicing the company's interests is also a fiduciary duty. Further, once the

78 Explanatory Notes, at para. [303]. For a fuller account of this development, see Lee, note 73 above, pp. $143-147$.

79 Lee, note 73 above, pp. 143 - 147. The specific designation of this obligation to disclose as a "duty" (under s. 177) would also resolve any doubt as to whether a breach of self-dealing rules would generate a claim for equitable compensation at law. For a discussion of this issue, see M. Conaglen, "Equitable Compensation for Breach of Fiduciary Dealing Rules" (2003) 119 L.Q.R. 146. 
disclosure obligation is justified on this basis, the objections to there being "positive" fiduciary obligations and the fear that such obligations would subsume other areas of law (in particular, the tort of negligence) no longer appear compelling. 